This item was submitted to Loughborough's Research Repository by the author.

Items in Figshare are protected by copyright, with all rights reserved, unless otherwise indicated.

\title{
Continuous scanning laser vibrometry for measurements on rotating structures
}

PLEASE CITE THE PUBLISHED VERSION

PUBLISHER

(C) Trans Tech Publications

VERSION

AM (Accepted Manuscript)

LICENCE

CC BY-NC-ND 4.0

\section{REPOSITORY RECORD}

Halkon, Ben J., and Steve Rothberg. 2019. "Continuous Scanning Laser Vibrometry for Measurements on Rotating Structures”. figshare. https://hdl.handle.net/2134/5606. 
This item was submitted to Loughborough's Institutional Repository (https://dspace.lboro.ac.uk/) by the author and is made available under the following Creative Commons Licence conditions.

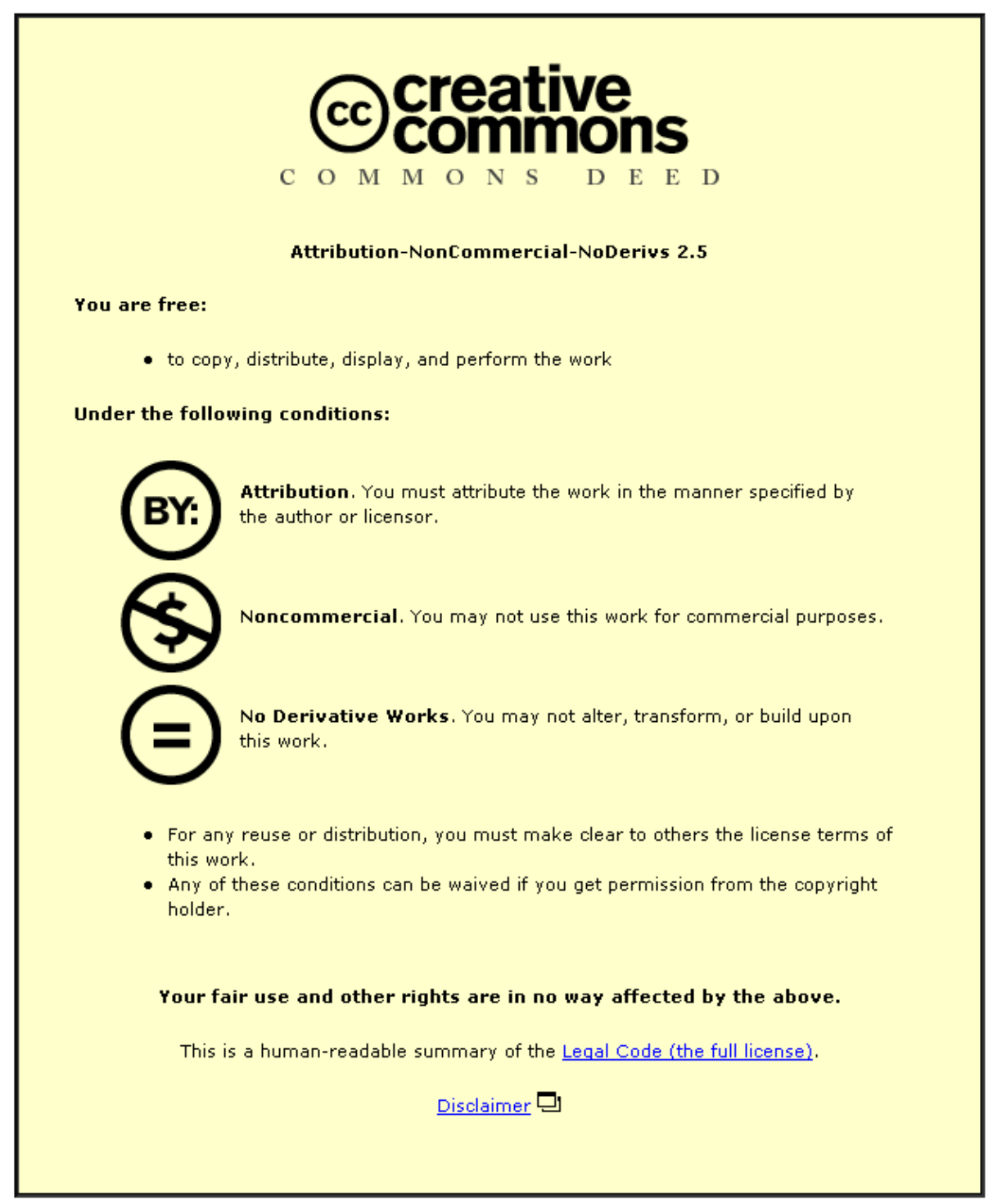

For the full text of this licence, please go to: http://creativecommons.org/licenses/by-nc-nd/2.5/ 